\title{
PENDAMPINGAN EKONOMI PERIWISATA DI DAERAH PERBATASAN (DESA TEMAJUK) MELALUI MANAJEMEN KEUANGAN DAN AKUNTANSI
}

\author{
Zulham Al Farizi, Oscar Rynandi A, Theresia Siwi Kartikawati, Linda Suherma, \\ Ninik Kurniasih, dan Desty Wana.
}

Jurusan Akuntansi, Politeknik Negeri Pontianak, Jalan Jenderal Ahmad Yani-Pontianak, Kalimantan Barat E-mail: Farizi85@gmail.com

\begin{abstract}
ABSTRAK. Pengabdian Pada Masyarakat (PPM( bertujuan untuk memfasilitasi keterampilan dan pengetahuan tentang pembukuan dan laporan keuangan kepada pelaku wisata dalam menyusun laporan keuangan dan menyiapkan akses permodalan di lembaga keuangan perbankan. Rincian kegiatan adalah seminar, pelatihan dan pendampingan dengan objek di Des Temajuk dan diadakan pada 17-18 September 2019. Peserta terdiri dari tiga puluh pelaku wisata yang tersebar di Desa Temajuk dari berbagai bisnis pariwisata seperti homestay, kafe/warung, dan perahu wisata. Dalam proses pelatihan, Tim PPM menggunakan pendekatan pendampingan dari mahasiswa yang terlibat. Kontribusi dari PPM ini adalah terbentuknya pemahaman dan kemampuan dalam menyiapkan laporan keuangan sederhana dan mempersiapkan persyaratan untuk akses perbankan. Hal ini dapat diidentifikasi dari kemampuan mereka dalam menyelesaikan siklus akuntansi. Berdasarkan survei setelah kegiatan kepada peserta, mereka sangat terbantu oleh kegiatan PPM ini dan menyukai metode yang digunakan dan tutor pendamping. PPM ini penting dan memberi dampak bahwa pemerintah harus menyiapkan serangkaian akses perbankan yang mudah diakses oleh penduduk Desa Temajuk.
\end{abstract}

Kata kunci: Pengabdian Pada Masyarakat; Pelaku wisata; Laporan keuangan; akses perbankan; Desa Temajuk

ABSTRACT. This community service (PPM) aims to facilitates skills and knowledge regarding bookkeeping and financial reports to tour operators. Purpose of this community service is helping tour operators in preparing bookkeeping and finanicial reports as requirement to capital access in financial institutions. The details of activities were seminars, training and mentoring by taking place in the village of Temajuk and held on 17-18 September 2019. Participants were thirty tour operators spread across Temajuk village from various tourism businesses such as homestay services, cafes/stalls, and tour boats. In the training process, the PPM Team used a mentoring approach from the students involved. Contributions of this community service were the understanding and capabilities in preparing simple financial reports and preparing requirements for banking access. It can be identified from their ability to complete the accounting cylus. Based on the survey after the activity to the participants, participants were greatly helped by community services activities and liked the methods used and the tutor. This community services is important and gives the impact that the government must prepare a range of banking access that is easily accessible to the Temajuk villagers.

Key words: community service; tourism actors; financial statement; banking access; Temajuk Villagers

\section{PENDAHULUAN}

Salah satu faktor penting dalam keberhasilan bisnis yaitu dibutuhkan literasi keuangan pada usaha kecil terhadap akuntansi yang berperan dalam mengelola, menjalankan serta mengembangkan usaha kecil itu sendiri (Panggabean, 2018:139). Terdapat berbagai sumber melalui pengetahuan yang dapat diperoleh. Semua pada berbagai tingkat kualitas atau keandalan. Ini termasuk pendidikan formal, yang didapatkan para pelaku usaha seperti program sekolah tinggi atau kuliah, seminar dan kelas pelatihan di luar sekolah.

Pengetahuan keuangan sangat penting sebagai dasar faktor kritis dalam pengambilan keputusan keuangan (Kusumawati, 2018:19). Walaupun banyak para pelaku usaha mungkin memiliki kapasitas yang kuat dalam mengatur pemasukan atas hasil usaha, tetapi dianggap masih memiliki kekurangan wawasan yang diperlukan untuk membuat keputusan keuangan yang bijaksana. Semakin baik pengetahuan tentang keuangan makin semakin baik pula dalam mengelola keuangan.

Pembangunan industri pariwisata seperti homestay, cafe maupun villa berbasis masyarakat merupakan upaya untuk meningkatkan ekonomi masyarakat khususnya masyarakat disekitaran wisata tersebut. Keterlibatan masyarakat dalam Pembangunan industri pariwisata juga merupakan salah satu cara pengembangan pariwisata berkelanjutan (Wedatama dan Mardiansjah, 2018:137). Mewujudkan hal tersebut pelaku industri pariwisata harus memahami tatakelola keuangan usaha secara baik.

Hanya saja pelaku industri pariwisata sebagian besarnya masih sangat tradisional dalam mengelola keuangan. Jika dilihat dari perkembangan kehidupan masyarakat pesisir perbatasan yang dinilai masih sulit dalam menghasilkan usaha dengan laba yang maksimal. Pemasukan uang dari hasil industri pariwisata sebagian dari pengelola digunakan untuk membiayai kehidupan mereka sehari-hari.

Tak terkontrolnya pengeluaran untuk biaya hidup dapat mengakibatkan masalah yang sering dialami oleh masyarakat para pelaku usaha. Hasil dari penyewaan atas industri pariwisata sebaiknya tidak digunakan seluruhnya dalam membiayai kebutuhan pelaku usaha. Jika pelaku usaha dapat mengelola hasil usahanya untuk perencanaan pengembangan usaha, maka tidak dipungkiri untuk kedepannya akan dapat memecahkan permasalahan yang dihadapi oleh masyarakat pesisir perbatasan dalam hal ekonomi. 
Biaya operasional ini didapat dari hasil sewa yang dibayarkan oleh wisatawan yang menginap. Seluruh biaya yang digunakan pelaku usaha dalam hal perbaikan, pemeliharaan, dan biaya lain yang dikeluarkan untuk kebutuhan sehari-hari dalam menunjang usahanya merupakan biaya operasional. Jika dilihat dari pengalokasian hasil sewa oleh para pelaku usaha ini dirasakurang tepat karena mereka mengalokasikan hasil usaha tersebut untuk biaya kebutuhan hidup mereka sehari-hari. Mereka masih cenderung berpikir jangka pendek dan identik dengan praktik belanja impulsif sehingga sering kali individu dengan pendapatan yang cukup masih mengalami masalah finansial karena perilaku keuangan yang kurang bertanggungjawab.

Penetapan tarif sewa industri pariwisata pada desa Temajuk masih belum memiliki dasar. Mereka menilai dan menaksir tarif sewa atas dasar kelayakan fasilitas yang digunakan. Padahal, pengenaan tarif sewa dinilai bukan hanya dari kelayakan fasilitas saja, namun masih ada faktor lainnya. Proses pembangunan homestay, cafe maupun villa menjadi salah satu faktor yang penting karena berpengaruh terhadap biaya produksi. Biaya produksi pada pendirian industri pariwisata terdiri dari biaya bahan baku langsung, biaya tenaga kerja langsung dan biaya jasa perencanaan (arsitek).

Industri pariwisata ini, pada umumnya belum menerapkan metode biaya standar dalam menentukan harga pokok produksi dan alat pengendalian biaya lainnya. Penetapan biaya standar dapat memberikan pedoman untuk mengetahui biaya yang seharusnya terjadi dalam proses pembangunan industri pariwisata. Biaya standar yang ditetapkan oleh pemilik usaha adalah untuk setiap jasa penginapan yang disewakan dalam jangka waktu satu tahun. Standar yang ditetapkan tersebut harus sudah tersusun diawal tahun sehingga dapat dipakai menjadi suatu landasan dalam proses pembangunan usaha.

\section{Pemahaman Mengolah Laporan Keuangan}

Berdasarkan Survei lapangan yang tim PPM lakukan sebelum kegiatan berlangsung dijelaskan bahwa terdapat berbagai sumber pengetahuan keuangan yang dapat diperoleh, semua pada berbagai tingkat kualitas atau keandalan. Tingkat pendidikan yang diperoleh di bangku sekolah pada desa Temajuk belum mengarah pada pengetahuan pengelolaan keungan. Mereka masih belum mengetahui pentingnya mengatur keuangan, baik dalam memenuhi kebutuhan hidup maupun dalam berbisnis membangun usaha. Artinya, pengetahuan yang diperoleh dari masyarakat mengenai keuangan pada kawasan perbatasan ini masih sangat rendah. Seperti yang diketahui, bahwa laporan keuangan merupakan hal yang penting bagi sebuah usaha sebagai dasar untuk mengambil keputusan dan menentukan strategi usaha yang akan dilakukan. Pihak perbankan juga menggunakan laporan keuangan sebagai informasi dan dasar pertimbangan bagi mereka untuk memberikan pinjaman. Melalui laporan keuangan yang sederhana pelaku usaha dapat melihat kesehatan usahanya. Oleh karena itu, laporan keuangan harus dibuat dengan baik dan benar. Akan tetapi, para pelaku industri pariwisata dikawasan pesisir perbatasan Temajuk masih belum menerapkan pembukuan atau akuntansi sederhana dalam menjalankan usaha.

\section{Kesulitan Akses Bantuan Pendanaan Untuk Pengembangan Usaha}

Modal merupakan komponen utama dalam wirausaha yang tidak bisa tergantikan oleh apapun. Berdasarkan Survei Lapangan yang tim PPM lakukan sebelum kegiatan dijelaskan bahwa industri pariwisata pada umumnya mengandalkan modal sendiri dalam menjalankan usahanya, dan terkadang mereka terjebak dengan keterikatan rentenir mengingat masih rendahnya aksesbilitas terhadap sumber-sumber pembiayaan formal pada kawasan pesisir perbatasan. Pelaku usaha mengalami kesulitan dalam membangun dan mengembangkan usaha penginapan sederhana karena mengandalkan modal dari tabungan sendiri, maka dalam permodalan ini memerlukan bantuan dari pemerintah.

Pelaku industri pariwisata di kawasan perbatasan menganggap bahwa modal usaha dapat dilakukan dengan tanpa bantuan pemerintah. Akan tetapi, mereka sangat kesulitan dalam mengumpulkan modal untuk membangun homestay, Caffe dan villa karena berasal dari tabungan pribadi. Keterbatasan akses informasi dan jarak tempuh yang jauh dalam mendapatkan modal dari perbankan maupun koperasi. Untuk datang ke kecamatan Paloh membutuhkan jarak tempuh sekitar $45 \mathrm{~km}$ (sekitar 2,5 - 3 jam dengan sepeda motor) dengan melalui sungai menggunakan kendaraan air yang disewakan oleh penduduk setempat. Informasi yang terbatas juga menjadi faktor kesulitan dalam mengakses sumber modal dari pemerintah.

Berdasarkan pemaparan di atas kami melihat bahwa untuk meningkatkan kemampuan dan pengembangan usaha homestay, cafee dan villa di kawasan perbatasan dapat dilakukan melalui peningkatakan kompetensi diri pelaku usaha. Kami berkeyakinan bahwa pelaku usaha yang telah memiliki kompetensi untuk mengembangkan usaha homestay, cafee dan villa akan dapat menjadi contoh bagi masyarakat sekitar karena itu kami mengusulkan program pengabdian masyarakat "Pendampingan Ekonomi Pariwisata di Daerah Perbatasan (Desa Temajuk) Melalui Manajemen Keuangan dan Akuntansi”.

\section{METODE}

\section{Manajemen Kas}

Kebanyakan orang mencari suatu kehidupan yang berkualitas dan keamanan keuangan. Masyarakat menginginkan untuk bisa membuat keputusan yang cerdas tentang bagaimana mengatur pengeluaran dan investasi serta akhirnya memperoleh suatu tingat kekayaan. 
Menurut Martono dan Agus (2007:116), menjelaskan bahwa Kas merupakan salah satu bagian dari aktiva yang memiliki sifat paling lancar dan paling mudah berpindah tangan dalam suatu transaksi. Kas yang dibutuhkan perusahaan, antara lain digunakan untuk operasional perusahaan sehari-hari seperti halnya untuk pembelian bahan baku dan bahan pembantu, membayar upah dan gaji, membeli supplies kantor habis pakai, pembayaran angsuran hutang, pembayaran pajak dan sebagainya. Kebutuhan kas untuk keperluan tersebut merupakan aliran kas keluar (cash outflow), sedangkan aliran kas masuk (cash inflow) sebagian besar berasal dari penjualan produk utama perusahaan. Perusahaan harus menentukan kas minimal yang harus ada di perusahaan, dan berapa besar kas yang ideal boleh disimpan agar operasional perusahaan tidak terganggu dan kas yang ada tidak menganggur sehingga menyebabkan kurangnya efisien perusahaan dalam menggunakan kas dan juga tidak menghasilkan keuntungan.

Penyusunan anggaran kas bagi perusahaan merupakan kegiatan yang sangat penting untuk kelang-sungan perusahaan. Perusahaan akan mengetahui keadaan kas yang ada secara pasti demi menjaga likuiditas perusahaan. Fokus anggaran kas adalah merencanakan penerimaan kas dan pengeluaran kas serta posisi saldo kas awal dan saldo kas akhir yang direncanakan untuk jangka waktu tertentu. Apabila kas tersebut dapat dikelola dengan baik, maka hal itu akan mampu mendukung semua unit kerja/ bisnis kedepan untuk menghadapi lingkungan bisnis yang semakin competitive.

Pengelolaan kas merupakan salah satu hal yang paling esensial karena survive tidaknya bisnis telekomunikasi yang makin futuristic, tergantung dari efektif tidaknya dua hal tersebut dikelola (Hadiana, 2006). Kas yang dimaksud disini adalah semua pendapatan di tiap unit bisnis dan dana dekonsentrasi yang diterima perusahaan. Kas merupakan salah satu aktiva lancar yang dimiliki oleh perusahaan. Oleh karena itu, pihak manajemen haruslah efektif dan efisien dalam mengelola kas karena kas adalah unsur modal kerja yang paling tinggi tingkat likuiditasnya sehingga keadaan kas yang tinggi atau rendah akan memberikan gambaran awal terhadap pengambilan keputusan manajemen perusahaan dan pihak investor kedepan disamping pengelolaan pajak.

\section{Biaya Operasional}

Dikemukakan oleh Rudianto (2009), bahwa biaya operasi merupakan biaya yang memiliki pengaruh besar terhadap keberhasilan perusahaan dalam mencapai tujuannya, yaitu memperoleh laba usaha. Pengeluaran biaya oleh perusahaan sebaiknya dikendalikan dengan baik, karena dengan mengendalikan biaya operasional, maka perusahaan dapat memperoleh laba yang optimal. Pengendalian biaya operasional tersebut mengakibatkan laba operasional yang meningkat. Penelitian ini sejalan dengan penelitian yang dilakukan oleh Pebriyanti (2013) meneliti Pengaruh Efisiensi Biaya Operasional Terhadap Laba Bersih dengan Perputaran Persediaan Sebagai Variabel Pemoderasi, menyatakan bahwa semakin besar biaya operasional maka semakin sedikit laba yang akan diterima.

\section{Penentuan Dasar Harga Tarif}

Harga adalah jumlah uang yang dibutuhkan untuk mendapatkan sejumlah barang atau jasa (Eka Penentuan (Trisnawan, 2014:3). harga tarif khususnya bidang pariwisata ditentukan oleh beberapa faktor, yaitu keadaan perekonomian, penawaran dan permintaan wisata, elastisitas permintaan wisata, persaingan terhadap jasa wisata, biaya, tujuan pengelola wisata dan pengawasan pemerintah. Penentuan dasar harga tarif wisata setiap daerah berbeda-beda tergantung dengan fasilitas dan keindahan alam yang ditawarkan. Pada dasarnya, dalam menetapkan harga tarif wisata disesuaikan dengan berdasarkan metode cost plus pricing (harga biaya plus), harga bersaing dan harga geografis. Semakin lengkap fasilitas, kenyamanan dan keindahan tempat wisata, maka harga yang ditawarkan juga relatif mahal (Handoyo, 2007:10-11).

\section{Laporan Keuangan}

Pada dasarnya Laporan Keuangan merupakan penghitungan rasio untuk menilai keadaan keuangan perusahaan dimasa lalu, saat ini dan kemungkinannya dimasa depan (Munawir, 2010:36). Analisis menggunakan rasio akan memberikan hasil pengukuran yang relatif dari operasional perusahaan. Pada umumnya ada tiga kelompok yang paling berkepentingan dengan rasio-rasio finansial, yaitu para pemegang saham dan calon pemegang saham, kreditur dan calon kreditur serta manajemen perusahaan.

Data keuangan yang dipergunakan untuk Analisis keuangan yang pokok, yaitu Neraca dan laporan Rugilaba.Analisis pada umumnya kedua laporan keuangan tersebut disajikan setahun sekali (yaitu pada akhir tahun kalender yang berakhir pada bulan Desember), meskipun sekarang terdapat kecenderungan untuk makin sering penyajiannya, misalnya setiap tiga bulan.

Menurut Kasmir (2013), menjelaskan bahwa neraca adalah laporan keuangan yang melaporkan jumlah kekayaan, kewajiban keuangan dan modal sendiri perusahaan pada waktu tertentu. Jumlah kekayaan disajikan pada sisi aktiva, sedangkan jumlah kewajiban dan modal sendiri disajikan pada sisi pasiva. Laporan Rugi-laba menunjukkan pendapatan dari penjualan, berbagai biaya dan laba yang diperoleh perusahaan selama periode tertentu.Dengan demikian, laporan rugilaba menunjukkan laporan selama satu periode, misalnya selama satu tahun sedangkan neraca menunjukkan laporan pada waktu tertentu.

\section{Akses Pendanaan Bagi Pengusaha}

Pergerakan pembangunan ekonomi di daerah, dalam prosesnya memerlukan ketersediaan peran serta lembaga 
keuangan sebagai sumber dana pembiayaan. Lembaga keuangan yang terlibat suatu pembiayaan pembangunan merupakan lembaga perantara keuangan sebagai sarana prasarana pendukung yang amat vital dalam menunjang kelancaran perekonomian daerah. Dalam UndangUndang Republik Indonesia Nomor 7 Tahun 1992, bahwa Peran lembaga keuangan yang akan didapat oleh masyarakat dari penyaluran dana oleh lembaga keuangan ini adalah sebagai wahana yang mampu menghimpun dan menyalurkan dana masyarakat secara efektif dan efisien kearah peningkatan taraf hidup masyarakat.

Penyaluran dana yang dilakukan oleh bank dilakukan dengan cara pemberian pinjaman yang biasa dalam masyarakat lebih dikenal dengan nama kredit. Kredit yang diberikan oleh bank terdiri dari berbagai macam jenis, tergantung dari kemampuan bank yang menyalurkannya. Demikian pula jumlah serta tingkat suku bunga yang ditawarkan. Sebelum kredit dikucurkan bank terlebih dahulu melakukan penilaian kelayakan kredit yang diaukan oleh nasabah. Kelayakan ini meliputi berbagai aspek penilaian. Penilaian kredit akan dikenakan bunga kredit yang besarnya tergantung dari bank yang menyalurkannya. Besar atau kecilnya bunga kredit sangat mempengaruhi keuntungan bank, mengingat keuntungan utama bank diperoleh selisih dari bunga yang diberikan kepada penyimpan (bunga simpanan) dengan bunga yang diterima dari peminjam (bunga kredit) (Nurfaizah dan Rika, 2015:3). Secara umum kredit yang ditawarkan adalah kredit investasi, kredit modal kerja, kredit konsumtif, kredit perdagangan, kredit produktif dan kredit profesi.

Sistem yang akan digunakan dalam melakukan kegiatan penerapan Iptek ini adalah menggunakan metode pelatihan, praktik, evaluasi dan tindakan korektif. (1) Pelatihan akan dilakukan pertama-tama untuk memberikan pemahaman sebagai berikut:

\section{Mengenalkan Keutamaan Fungsi dari Manajemen Keuangan}

Mengenalkan keutamaan keahlian yang wajib dimiliki pelaku usaha dalam berbisnis pada sektor jasa. Pengenalan ini dilaksanakan dengan tahap-tahap sebagai berikut:

1) Memberikan motivasi kepada pelaku usaha melalui keutamaan atau dasar-dasar pengetahuan manajemen yang wajib dimiliki dalam proses bisnis.

2) Mengenalkan fungsi-fungsi dari manajemen keuangan yang dapat digunakan dalam kehidupan sehari-hari dalam berbisnis. Termasuk disini cara-cara menyikapi masalah yang biasa terjadi dalam praktik manajemen keuangan yang dilaksanakan pada bisnis jasa selama ini.

\section{Mengenalkan Praktik Umum Akuntansi pada Sektor Jasa}

Pengenalan praktik akuntansi di dunia bisnis sektor jasa yang saat ini dilakukan pengusaha. Pengenalan ini dilaksanakan dengan beberapa tahap sebagai berikut:
1) Mengenalkan real praktik proses bisnis dan catatancatatan akuntansi yang tersedia dari transaksi akuntansi yang dihasilkan dalam proses bisnis. Termasuk disini diuraikan kelamahan - kelemahan dari praktik akuntansi yang dilaksanakan selama ini.

2) Mengenalkan kemampuan dasar akuntansi yang sebenarnya dibutuhkan dalam dunia bisnis sektor jasa.

\section{Metode Penyusunan Laporan Keuangan dari Data Yang Tersedia}

1) Mengenalkan konsep dan proses bagaimana menyusun laporan keuangan sederhana dengan mendasarkan pada data yang ada. Termasuk disini mengumpulkan komponen-komponen laporan keuangan, merapikan serta mengarsipkan data yang tersedia.

2) Mengenalkan real praktik penyusunan laporan keuangan dengan sistem akuntansi yang sederhana.

Setelah sesi pelatihan dilakukan maka akan dilaksanakan (2) praktik mandiri, bedanya dengan yang diatas adalah kalau yang diatas praktik menggunakan modul yang sudah disiapkan olehpanitia, maka dalam praktik mandiri peserta diminta untuk mengerjakan kasus secara mandiri. (3) Evaluasi lalu akan akan diberikan terhadap hasil setelah mereka menuntaskan praktikmandiri. Terakhir akan dilakukan tindakan (4) korektif untuk memperbaiki pekerjaan mereka apabila ditemukan masih terdapat ketidaksesuaian dengan kaidah, prosedur, dan peraturan akuntansi/perpajakan. Dengan metode seperti maka kami yakin tujuan kegiatan akan tercapai.

Melakukan undangan/seleksipeserta; berjasama dengan Pemerintah Desa Temajuk, Kecamatan Paloh, Kabupaten Sambas.Kami menyurati Pemerintah Desa untuk membantu memfasilitasi kami mendapatkan peserta yang relevan. Pertimbangannya adalah Pemerintah Desa tentulah memiliki databasepelaku wisata di Desa Temajuk.

1) Undangan peserta \& Perwakilan Desa; Setelah kami mendapatkan daftar calon peserta pelatihan, kami menyebarkan undangan ke alamat masing-masing peserta berdasarkan data yang kami dapatkan dari Pemerintah Desa.Kami juga mengundang BABINSA dan BABINKANTIBMAS untuk ikut serta dalam kegiatan tersebut.

2) Menyiapkan bahan pelatihan; Menyusun bahan pelatihan berupa penyiapan simulasi kasus, pengetikan, penjilidan dan pengujian yang dilaksanakan secara tim. Bahan disiapkan dengan menyesuaikan karakteristik peserta yang berdasarkan biodata umumnya adalah dari kalangan pelaku wisata dengan ilustrasi kasus penyewaan homestay, cafee dan villa.

3) Arangment tempat kegiatan; Kegiatan ini meliputi permohonan peminjaman Gedung Serbaguna Desa Temajuk ke kantor Desa Temajuk karena berdasarkan pertimbangan, tempat inilah yang paling representative. Selain itu juga disiapkan baliho, sound system, dan 
tata letak ruangan yang memudahkan untuk kegiatan dengan format seminar dan pelatihan.

\section{HASIL DAN PEMBAHASAN}

Jumlah peserta yang mengikuti kegiatan adalah 30 peserta yang berasal dari beragam pelaku Industri pariwisata seperti homestay, cafe dan villa. Para pelaku Industri pariwisata yang mengikuti kegiatan ini tersebar di daerah Desa Temajuk. Pencapaian ini tidak lepas dari adanya sistem antisipasi yang baik karena dilakukan melalui proses seleksi, undangan dan konfirmasi kesediaan dan kepastian hadir yang baik. Berikut adalah daftarnya".

\section{Tabel 1. Daftar Peserta}

\begin{tabular}{|c|c|c|}
\hline No & Nama Peserta & Bidang Wisata \\
\hline 1 & Dwi Aryanto & Homestay \\
\hline 2 & M. Umar & Homestay \\
\hline 3 & Herlin & Café \\
\hline 4 & Laiman & Villa \\
\hline 5 & Hairiah & Homestay \\
\hline 6 & Juana & Homestay \\
\hline 7 & Mislia & Café \\
\hline 8 & Muriyadi & Homestay \\
\hline 9 & Asmani & Homestay \\
\hline 10 & Winarti & Homestay \\
\hline 11 & Jupri & Homestay \\
\hline 12 & Ani & Homestay \\
\hline 13 & Dedy. C & Homestay \\
\hline 14 & Joko & Villa \\
\hline 15 & Gustiar & Homestay \\
\hline 16 & Jiko & Perahu Wisata \\
\hline 17 & Wendi & Villa \\
\hline 18 & Intan & Homestay \\
\hline 19 & Junaidi & Homestay \\
\hline 20 & Rasad & Homestay \\
\hline 21 & Yayang Triani & Villa \\
\hline 22 & Johani & Perahu Wisata \\
\hline 23 & Saman & Homestay \\
\hline 24 & Tabiin & Café \\
\hline 25 & Wiradi & Homestay \\
\hline 26 & Wahyudi & Villa \\
\hline 27 & Siswandi & Homestay \\
\hline 28 & Burhanudin & Homestay \\
\hline 29 & Agil. F & Homestay \\
\hline 30 & Suryadi & Homestay \\
\hline
\end{tabular}

Kegiatan terlaksana dengan baik dan lancar tanpa kendala yang cukup berarti. Diakhir kegiatan kami melakukan evaluasi kepada semua peserta dengan menanyakan respon mereka terhadap kegiatan. Hasilnya adalah dijelaskan pada tabel 2.

Setelah kegiatan selesai, kami melakukan evaluasi kegiatan pelatihan dengan menanyakan respon peserta terhadap kegiatan pelatihan. Berikut adalah ringkasan hasil evaluasi kegiatan dari 30 peserta.

Kami juga memberikan pertanyaan terbuka mengenai apa yang mereka sukai di Seminar \& Pelatihan ini? Jawaban mereka kami kelompokkan dalam lima kategori:

1) Praktik Langsung Bukan Sekedar Teori

2) Narasumber menyampaikan materi jelas dan mudah dipahami

3) Tutor yang friendly (Sopan \& Mudah di Pahami)

4) Lain-lain (seperti topic modal usaha, peluang usaha, tempat kegiatan dll)

5) Tidak Menjawab

Gambar 1 di bawah ini memberikan gambaran mengenai respon mereka.

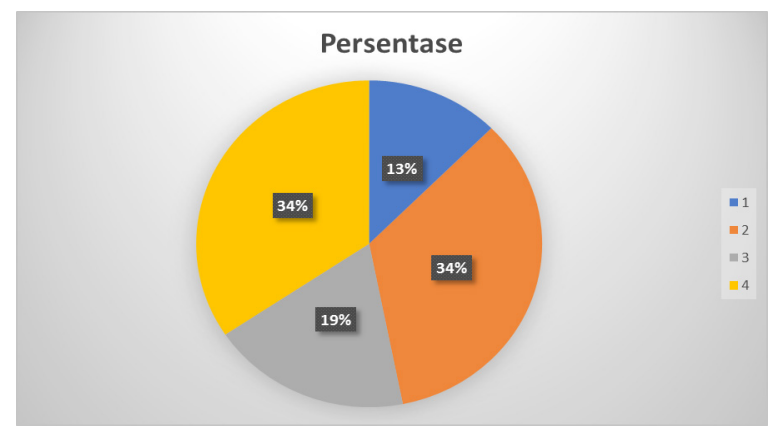

Gambar 1. Survei Respon Atas Seminar \& Pelatihan

Apa yang mereka harapkan dan usulkan untuk kegiatan Seminar dan Pelatihan yang akan datang? $34 \%$ menjawab agar kegiatan seperti dilaksanakan kembali. 19\% mengatakan agar kegiatan ini adapenambahan waktu, 13\% mengatakan agar kegiatan ini ada tindak lanjutnya seperti pendampingan. Dan sisanya 34 persen menyatakan saran dan perbaikan seperti kualitas cetakan modul yang lebih baik, kemudian ada juga yang menyarankan agar dipraktekan langsung kepada peserta.

Tabel 2: Evaluasi Kegiatan

\begin{tabular}{|c|c|c|c|c|c|}
\hline Item Pertanyaan & Tidak Baik & $\begin{array}{c}\text { Kurang } \\
\text { Baik }\end{array}$ & Cukup & Baik & Sangat Baik \\
\hline \multicolumn{6}{|c|}{ loci } \\
\hline Lokasi kegiatan & $0 \%$ & $0 \%$ & $0 \%$ & $20 \%$ & $80 \%$ \\
\hline Narasumber & $0 \%$ & $0 \%$ & $0 \%$ & $50 \%$ & $50 \%$ \\
\hline Pengaturan ruangan & $0 \%$ & $0 \%$ & $10 \%$ & $70 \%$ & $30 \%$ \\
\hline Makanan & $0 \%$ & $0 \%$ & $0 \%$ & $40 \%$ & $60 \%$ \\
\hline \multicolumn{6}{|c|}{ Isan dalam sesi-sesi berikut: } \\
\hline Penentuan Tarif Jasa Wisata & $0 \%$ & $0 \%$ & $0 \%$ & $80 \%$ & $20 \%$ \\
\hline Pengelolaan Biaya & $0 \%$ & $0 \%$ & $0 \%$ & $80 \%$ & $20 \%$ \\
\hline Manajemen Kas & $0 \%$ & $0 \%$ & $10 \%$ & $50 \%$ & $40 \%$ \\
\hline Akses Perbankan & $0 \%$ & $0 \%$ & $10 \%$ & $60 \%$ & $30 \%$ \\
\hline Keseluruhan & $0 \%$ & $0 \%$ & $2,5 \%$ & $56,25 \%$ & $41,25 \%$ \\
\hline
\end{tabular}


Sebagai salah satu bentuk pertanggungjelasan kegiatan kemudian diberitakan melalui web UPPM Polnep dan chanel media massa youtube (https://www.youtube.com/ watch? $v=j 99 E d L N p e 2 M)$. Untuk pemberitaan dapat dilihat di linkhttp://uppm.polnep.ac.id/?p=2824. (ada di koran dan di ajukan untuk dipublikasikan adapun bukti pengajuan tersebut kami lampirkan).

\section{Hasil Kegiatan \& Pembahasan}

Berdasarkan pemantauan selama kegiatan peserta 96\% berhasil menyelesaikan siklus yang menjadi ilustrasi dalam kegiatan. Selesainya sebagian besar siklus oleh peserta dalam pandangan kami karena adanya faktor pertama adalah memberikan ilustrasi dan penyampaian bahasa yang mudah dipahami. Yang kedua adalah adanya tutor pendamping yakni mahasiswa yang dilibatkan. Para tutor pendamping terlebih dahulu telah dilatih keahliannya dan diajarkan etika pendampingan sehingga pada saat totor pendamping melakukan pendampingan secara personal mereka berterima di semua peserta. Peserta menjadi nyaman bertanya dan lebih mudah memahami.

Mereka menjadi memiliki pengalaman menggunakan pembukuan sesuai standar akuntasi sederhana sehingga memiliki kepercayaan untuk mengaplikasikannya. Selama kegiatan mereka mengakui bahwa model pelatihan seperti ini berbeda dari pelatihan biasanya yang hanya berupa ceramah-ceramah. Pelatihan seperti menciptakan pengalaman tersendiri. Tentu saja hal ini sejalan dengan yang diproposisikan di awal bahwa ketika suatu pekerjaan, dalam konteks ini menyusun laporan keuangan. Pelatihan ini adalah bentuk external support bagi mereka untuk memahami pencatatan keuangan bisnis mereka sesuai dengan standar akuntansi.

Akses perbankan yang selama ini kurang dikenal mereka, dengan berbagai factor pertimbangan. Salah satunya adalah jangkauan akses jalan menuju bank terdekat masih terlalu jauh dari desa. Selain itu, mereka berfikir bahwa akses perbankan dalam memperoleh dana tambahan untuk mengembangkan usaham mereka sangat sulit. Dengan pemahaman yang telah diberikan bahwa kemudahan akses perbankan itu tidak terlalu sulit dijangkau mereka. Dengan demikian mereka akan mempertimbangkan bahwa dalam mengembangkan usahanya dapat menggunakan modal dari perbankan.

Meski dalam dunia praktis nanti mereka tidak harus menggunakan pembukuan dan akses perbankan, karena mereka merasa masih cukup dengan besarnya usaha sekarang. Namun, Dengan berbekal pengalaman setidaknya mereka dapat memanfaatkan akses dari perbankan suatu saat nanti. Bahkan mereka akan merasa perlu dalam melakukan pembukuan usahanya karena keingintahuan mereka apakah usaha yang mereka jalani ini berkembang atau tidak. Tentu tidak akan terlalu sulit, terlebih lagi pelaksana PPM menyediakan kontak yang bisa dihubungi agar mereka bisa melakukan bimbingan secara berkelanjutan sebagai bentuk komitmen kami untuk menjadi external support bagi mereka.

\section{SIMPULAN}

Simpulan dari kegiatan ini adalah: PPMharus direncanakan dengan baik, disiapkan dengan baik (test case) dan ditujukan ke khalayak sasaran yang tepat serta disesuaikan dan dicocokkan dengan keahlian yang dimiliki TIM PPM; Dalam proses perancangan pelaksanaan kegiatan PPM harus memperhatikan riset-riset pendahuluan terkait dengan isu terkini dalam konteks PPM dan menganalisis kebutuhan khalayak sasaran; Akses perbankan yang dapat digunakan dalam mengembangkan usaha pelaku wisata, dinilai cukup efektif dalam menjadi pilihan pelaku wisata untuk mengembangkan usaha mereka.

\section{UCAPAN TERIMAKASIH}

Atas kelancaran kesuksesan kegiatan kami ingin menyampaikan ucapan terima kasih kami dan aprisiasi yang setinggi-tingginya kepada pihak-pihak berikut ini:

1) Direktur Politeknik Negeri Pontianak, Bapak Ir. H M. Toasin Asha, M.Si

2) Pemerintah Desa Temajuk atas kerjasamanya dalam memfasilitasi kami mendapatkan peserta yang relevan.

3) Kepala Unit Penelitian dan Pengabdian Pada Masyarakat Poiliteknik Negeri Pontianak, Bapak Prof. Dr. Ardi Marwan, M.Ed, atas dukungan selama kegiatan.

4) Ketua Jurusan Akuntansi, Bapak Dr. A Razak Alqadrie, SE, MM, Ak, CA, yang juga selaku reviewer PPM ini.

5) Peserta kegiatan yang telah berkenan berpartisipasi dalam kegiatan.

6) Mahasiswa yang terlibat atas kerja keras kalian menyiapkan kegiatan dan mendampingi peserta selama pelaksanaan kegiatan.

\section{DAFTAR PUSTAKA}

Dian, R. (2019). Inilah Faktor Yang Mempengaruhi Kesuksesan Wirausaha. (Online) (Https://www. Beecloud.Id/Inilah-Faktor-Yang-MempengaruhiKesuksesan-Wirausaha/, Diakses 10 Desember 2019).

Hadiana, R.F. (2006). Analisis Manajemen Kas Pt. Telkom Divre Vii Makassar Dalam Rangka Peningkatan Pendapatan Non-Operasional: Studi Kasus Di Pt Telkom Divre Vii Makassar. Bandung: Institus Manajemen Telkom. .

Handoyo, H.L. (2007). Penentuan Tarif Perjalanan Wisata. Universitas Sanata Dharma Yogyakarta

Ikhtiari, K \& Arfah, E.A. (2017). Perbandingan Analisa Laporan Keuangan Perusahaan Jasa Dan Pabrikasi Untuk Menilai Kinerja Perusahaan. Akuntabilitas, 10, (2). 
Kasmir. (2011) Dasar-Dasar Perbankan, Jakarta, Pt Raja Grasindo Persada.

Kusumawati, I. (2018). Pengaruh Lingkungan Keluarga Dan Financial Literacy Terhadap Perilaku Mahasiswa Dalam Mengelola Keuangan (Studi Pada Mahasiswa Jurusan Perbankan Syariah Febi Iain Surakarta). Ekonomi Dan Bisnis Islam Institut Agama Islam Negeri Surakarta

Munawir. (2010). Analisa Laporan Keuangan. Yogyakarta: Liberty.

Ningtyas, C.P., Suhadak, \& Nuzula, N.F. (2016). Evaluasi Kinerja Dan Perbandingan Analisis Rasio (Studi Pada Sektor Makanan Dan Minuman Yang Terdaftar Di Bursa Efek Indonesia Periode 20102014. Jurnal Bisnis Dan Manajemen, 3, (2).

Nurfaizah, \& Parmitasari, R.D.A. (2015). Pengaruh Tingkat Suku Bunga Deposito Terhadap Jumlah Dana Deposito Pada Bank Mandiri Cabang Utama Makassar.Fakultas Ekonomi Dan Bisnis Islam.Uin Alauddin Makkassar.

Nurfaizah, \& Parmitasari, R.D.A. (2015). Pengaruh Tingkat Suku Bunga Deposito Terhadap Jumlah Dana Deposito Pada Bank Mandiri Cabang Utama Makassar. Fakultas Ekonomi Dan Bisnis Islam Uin Alauddin Makkassar.

Panggabean, Yani, F. (2018). Analisis Literasi Keuangan Terhadap Keberlangsungan Usaha Kuliner Kota Medan. Jurnal Manajemen Dan Keuangan, 7, (2).
Pebriyanti. (2013). Pengaruh Efisiensi Biaya Operasional Terhadap Laba Bersih Dengan Perputaran Persediaan Sebagai Variabel Pemoderasi(Studi Kasus Pada Pt. Petro Multi Guna Tanjungpinang)

Ramadhan, N. (2014). Komputer Akuntansi Dan Manfaatnya Bagi Alam Pekerjaan, Zahir Accunting, Jakarta.

Rudianto. (2009). Akuntansi Manajemen. Yogyakarta: Grasindo

Suwardjono, (2011). Akuntansi Pengantar 1: Proses Penciptaan Data, Pendekatan Sistem, Yogyakarta: Bpfe

Trianto, A. \& Bastian, S. (2012). Myob Versi 18. Penyelesaian Kasus Pendekatan Bukti Transaksi. Yogyakarta: Penerbit Andi.

Trisnawan, A.D. (2014). Pengaruh Kualitas Produk, Harga, Promosi Dan Distribusi Terhadap Loyalitas Konsumen Handphone Samsung Di Semarang. Universitas Dian Nuswantoro.

Trisnawati, F. \& Situmorang, J.W.P. (2015). Kualitas Laporan Keuangan Ukm Di Kota Pekanbaru. Jurnal Al-Iqtishad, 11, (1).

Undang-Undang Republik Indonesia Nomor 7 Tahun 1992 Tentang Perbankan.

Wedatama, A.A. \& Mardiansjah, F.H. (2018). Pengembangan Homestay Berbasis Masyarakat Pada Kampung Homestay Borobudur. Jurnal Pengembangan Kota, 6, (2), 135-143. 